\title{
Hexavalent Chromium Induced Histological Alterations in Bacopa monnieri (L.) and Assessment of Genetic Variance
}

\author{
Shilpi Khare Saikia*, Arun Kumar Mishra, Sudeep Tiwari and Rakesh Pandey \\ Microbial Technology and Nematology, CSIR- Central Institute of Medicinal and Aromatic Plants, Lucknow, India
}

\begin{abstract}
Chromium, a transition metal exists in nature in several oxidation states, the most important being $\mathrm{Cr}$ (III) and $\mathrm{Cr}$ (VI) species. The two forms display quite different chemical properties as $\mathrm{Cr}(\mathrm{VI})$ is highly toxic to most organisms whereas $\mathrm{Cr}(\mathrm{III})$ is relatively innocuous. $\mathrm{Cr}(\mathrm{VI})$ exposures are responsible for carcinogenic and mutagenic effects in humans also. The present study investigates the changes in cortical and vascular tissues of Bacopa monneiri after short-term exposure to $\mathrm{Cr}(\mathrm{VI}) . \mathrm{K}_{2} \mathrm{Cr}_{2} \mathrm{O}_{7}(0.05 \mathrm{M})$ was added to Murashige and Skoog's (MS) media to which Bacopa explants were introduced and the detrimental effects were studied after 21 days of incubation under different stress conditions. Histological results revealed a time-dependent noxious effect of $\mathrm{Cr}(\mathrm{VI})$ on cortical cells. The amount of damage in vascular region was observable but not much defined. Changes included enlargement of the cortical cells and accumulation of chromium within the live tissues. The molecular interpretation of damage due to $\mathrm{Cr}$ ( $\mathrm{VI}$ ) was done by PCR amplification of different antioxidant genes and analysing the products on $1 \%$ agarose gel. The genes were unable to show expression with cDNA template from explants exposed to $\mathrm{Cr}(\mathrm{VI})$ while with cDNA from explants exposed to bacterial isolates and chromium, expression of antioxidant genes was observed. The study will provide glimpses of $\mathrm{Cr}(\mathrm{VI})$ induced damage in plant tissue at cellular and genetic levels.
\end{abstract}

Keywords: Cr (VI); Histological changes; Bacopa monneiri; Cr (VI) reduction

\section{Introduction}

Industrial effluents contain a large number of toxicants such as salts of heavy metals, acids, organic matter, and pesticides etc. which deteriorate the physico-chemical characteristics of water. These pollutants build up in the food chain affecting the inhabitant and nearby flora and fauna. Among heavy metals, chromium $(\mathrm{Cr})$ is one of most toxic metals. Chromium occurs in oxidation states of $\mathrm{Cr}$ (II) to $\mathrm{Cr}$ (VI) but only $\mathrm{Cr}$ (III) and $\mathrm{Cr}(\mathrm{VI})$ are of biological significance as stable forms. An essential micronutrient for human diet, $\mathrm{Cr}$ (III) is relatively less toxic than $\mathrm{Cr}(\mathrm{VI})$, which is toxic, mutagenic and carcinogenic [1]. $\mathrm{Cr}$ (VI) is derived from the oxidation of ores and also from the combustion of the fossil fuels, wood and paper and is relatively stable in water. It causes irritation to sensitive epithelial lining and results in ulceration [2]. $\mathrm{Cr}(\mathrm{VI})$ is equally toxic to plants and affects various aspects of plant metabolism [3]. Accumulation of Cr (VI) by plants can reduce growth, induce chlorosis, reduce pigment content, alter enzymatic functions and can cause ultra structural modifications in cell membrane [4]. $\mathrm{Cr}$ (VI) toxicity can reduce seed germination and radical growth in plants due to inhibition of cell division by inducing chromosomal aberrations [5]. Hence, it is almost impossible to grow plants at or near Cr (VI) contaminated soils. Therefore, suitable methods need to be developed for remediation of $\mathrm{Cr}$ (VI) contaminated soils. Also it becomes relevant to study the impact of chromium on antioxidant defence system and other biochemical changes in plant metabolism.

Chromium (Cr) is discharged into the environment through improper disposal of wastes from industries like leather tanning, metallurgical and metal finishing, textiles and ceramics, pigment and wood preservatives, photographic sensitizer manufacturing etc. Effluents from these processes are strongly acidic and may contain the toxic $\mathrm{Cr}(\mathrm{VI})$ or the less toxic trivalent form [6]. Cr (VI) remains stable for several months in the soil without changing its oxidation state. $\mathrm{Cr}$ (VI) is accumulated by plants and its accumulation is biomagnified at different trophic levels through food chain [7]. The medicinal plants constitute, a large group of plants (both lower and higher) providing raw materials for use in drug formulation and related industries. If such plants are either naturally grown or cultivated in metal contaminated regions, there is a danger that the heavy metal accumulation by plants of medicinal value may cause serious health hazards to patients using metal adulterated herbal drugs. There are a number of reports on heavy metal accumulation by some essential oil yielding and other medicinal plants [8]. The contamination of heavy metals in market samples of some plant-based drugs has also been reported [9]. Hence, it becomes necessary that medicinal plants are first tested for metal contamination before exploiting them for medicinal uses.

Bacopa monnieri (L.), commonly known as "Brahmi" is a creeping herb from the family Scrophulariaceae. It is commonly found on the banks of rivers and lakes widely used to evaluate the physiological changes in the contaminated ecosystems. B. Monnieri, the medicinal plant has been used for centuries in folklore and traditional system of medicine as a memory enhancer, anti-inflammatory, analgesic, antipyretic, sedative and anti-epileptic agent, posing its importance as a medicinal plant [10]. In addition to its unique medicinal use, $B$. monnieri has also been linked to phytoremediation programmes for the removal of heavy metals such as cadmium and chromium [11].

Histological studies are a noteworthy and promising field to understand the changes in structural organization that occur due to pollutants in the environment. These structural changes vary with the

${ }^{*}$ Corresponding author: Shilpi Khare Saikia, Microbial Technology and Nematology Division, CSIR-Central Institute of Medicinal and Aromatic Plants, P.O.-CIMAP, Lucknow, India 226015, E-mail: shilpisaikia@yahoo.co.in

Received March 03, 2012; Accepted April 09, 2012; Published April 12, 2012

Citation: Shilpi Khare S, Arun Kumar M, Sudeep T, Rakesh P (2012) Hexavalent Chromium Induced Histological Alterations in Bacopa monnieri (L.) and Assessment of Genetic Variance. J Cytol Histol 3:141. doi:10.4172/2157-7099.1000141

Copyright: ( 2012 Shilpi Khare S, et al. This is an open-access article distributed under the terms of the Creative Commons Attribution License, which permits unrestricted use, distribution, and reproduction in any medium, provided the original author and source are credited. 
complexity of tissue, nature of the pollutant, medium and duration of exposure [12]. Mostly such studies are focussed on the aquatic fishes assessing haematological, biochemical and immunological parameters. However, scientific evidence of toxicological impact of chromium associated with nearby flora is still rare. Amongst various remedial strategies, bioremediation is a better choice for rehabitation and reclamation of chromium contaminated sites. Genes from microbes, plants, and animals are being used successfully to enhance the ability of plants to tolerate, remove, and degrade pollutants. The most important criteria in successful bioremediation employing microbes are the ability of these microbes to possess desired metabolic activity i.e. $\mathrm{Cr}$ (VI) tolerance for surviving in polluted environment. Endophytic microbes are thus evaluated for bioremediation studies, as they share a common environment with their host plants, offering a better range of adaptation.

The present study focuses on understanding the histological and genetic changes associated with $\mathrm{Cr}$ (VI) in a common medicinal plant B. monneiri. The impact of chromium tolerant endophytic bacteria, Bacillus megaterium (NCBI Acc. No. JQ585719) and CIM 1 in neutralization of chromium disaster and their influence on plant growth and survival are evaluated. The exploration will also brighten the histological alterations occurring in flora, inhabiting the contaminated sites.

\section{Materials and Methods}

\section{Medium and culture conditions}

Murashige and Skoog's, MS medium [13] of half nutrient strength was used for this study. This was prepared by adding $3 \%(\mathrm{w} / \mathrm{v})$ sucrose (Hi-Media, Mumbai, India) to MS basal salts; $\mathrm{pH}$ of the medium was adjusted to 5.8 using $0.1 \mathrm{M} \mathrm{NaOH}$ before adding $0.6 \%(\mathrm{w} / \mathrm{v})$ agar (Bacteriological grade) (Hi- Media, Mumbai, India) and the medium was autoclaved at $121^{\circ} \mathrm{C}$ for 15 mins. Based on the experiment, two different endophytic bacteria (Table 1) having $50 \mu \mathrm{g} / \mathrm{ml}$ tolerances for $\mathrm{Cr}$ (VI) were added to the MS basal medium with pH5.6, before adding the agar. The endophytic bacteria selected were Bacillus megaterium (NCBI Acc. No. JQ585719) and CIM 1, possessing plant growth promoting activities. A preliminary study for shoot induction was carried out for 21 days after which the observations were recorded.

\section{Plant material}

B. monnieri plants were collected from the medicinal plant garden at CIMAP, CSIR-India. Leaf and internode explants were prepared according to surface decontamination procedure [14]. Briefly, shoots were washed in sterile water for 15 mins, soaked in Triton-100 for 5 mins and finally washed three times with sterile distilled water. Surface decontamination was performed by immersing shoot tips in $70 \%(\mathrm{v} / \mathrm{v})$ alcohol for 30 seconds, treated for 3 mins with $0.1 \%$ (w/v) $\mathrm{HgCl}_{2}$ (HiMedia, Mumbai, India) and washed six times with sterile distilled water. Shoots with a single node $(2 \mathrm{~cm})$ were placed in the MS medium. Plants produced from this culture (after 3 weeks) were used for the subsequent experiments.

\section{Chromium (VI) concentration}

The explants were subjected to various treatments after exposing to $50 \mu \mathrm{g} / \mathrm{ml}$ of chromium (VI) $\left(\mathrm{K}_{2} \mathrm{Cr}_{2} \mathrm{O}_{7}\right)$. The effect of dark photoperiod, UV-light and temperature on the growth of explants were also studied with reference to control plants. The efficiency of growth promotion ability of both the endophytic bacteria (B. megaterium and CIM
1) under stress of toxic $\mathrm{Cr}$ (VI) concentration and also temperature $\left(30^{\circ} \mathrm{C}\right)$ was evaluated. The various treatments observed are illustrated (Table 1).

\section{Histological analysis}

Thin transverse section of treatment no. 1, 2, 3 and 4 (Table 1) were cut with the help of a sharp scalpel and double stained for better resolution of the cells. The sections were observed at $100 \mathrm{x}$ magnification by OLYMPUS, Japan microscope and recorded with the help of Catcam microscope eyepiece digital camera.

\section{Evaluation of heavy metals tolerance and $\mathrm{Cr}$ (VI) reduction ability among endophytes}

The Minimum Inhibitory Concentration (MIC) was determined on Luria agar (LA) plates amended with Cr (VI) concentration ranging from $25-100 \mu \mathrm{g} / \mathrm{ml}$. The minimum concentration of the metal inhibiting complete growth after $24 \mathrm{hrs}$ of incubation at $25^{\circ} \mathrm{C}$ was taken as the MIC. For estimation of $\mathrm{Cr}$ (VI) reduction, the endophytes were grown in peptone broth supplemented with $50 \mu \mathrm{g} / \mathrm{ml}$ concentrations of Cr (VI). All the inoculated flasks and controls (in triplicate) were incubated for $72 \mathrm{hrs}$ at $10^{\circ} \mathrm{C}$ with shaking at $100 \mathrm{rpm}$. To measure the $\mathrm{Cr}(\mathrm{VI})$ reduction, $1 \mathrm{ml}$ culture was centrifuged $(6000 \mathrm{rpm}, 10 \mathrm{mins}$ at $10^{\circ} \mathrm{C}$ ) and $\mathrm{Cr}(\mathrm{VI})$ in the supernatant was estimated according to the 1 , 5-diphenyl carbazide method [15].

\section{Statistical analysis}

A record for shoot length, fresh weight and dry weight for all the treatments was maintained and was analysed by one- way ANOVA using Assistat software version 7.6 beta (2011). The significance of the data was analysed at $\mathrm{p}>0.005$.

\section{RNA isolation and amplification of antioxidant genes}

Total RNA was isolated from the explants of treatment 1, 2, 3 and 4 by Trizol Mini-Prep method. First strand cDNA synthesis was done following the manufacturer's protocol (In-Vitrogen, India). The integrity of cDNA was checked by the amplification of actin housekeeping genes and further quantification of different antioxidant genes (SOD and Catalase) was done using equivalent amount of cDNA template.

\section{Results}

\section{Histological results}

Histological studies provide an insight into cellular processes and clues for the proposal of hypothesis for further experimentation. In the control explants (Treatment 1), no damage to the tissues was observed. The transverse section of control plant showed continuous mass of

\begin{tabular}{|c|c|}
\hline Experiment & Parameter details \\
\hline Treatment 1 & Control with no Cr VI. \\
\hline Treatment 2 & Explant with $50 \mu \mathrm{g} / \mathrm{ml} \mathrm{Cr}(\mathrm{VI})$ \\
\hline Treatment 3 & Explant with $50 \mu \mathrm{g} / \mathrm{ml} \mathrm{Cr}(\mathrm{VI})$ and Bacillus megaterium . \\
\hline Treatment 4 & Explant with $50 \mu \mathrm{g} / \mathrm{ml} \mathrm{Cr}(\mathrm{VI})$ and endophyte CIM 1. \\
\hline Treatment 5 & Explant without Cr VI incubated in dark conditions. \\
\hline Treatment 6 & Explant with no Cr VI exposed toUV- light. \\
\hline Treatment 7 & Explant with Bacillus megaterium incubated at $20^{\circ} \mathrm{C}$. \\
\hline Treatment 8 & Explant with endophyte CIM 1 incubated at $20^{\circ} \mathrm{C}$. \\
\hline Treatment 9 & Explant with Bacillus megaterium incubated at $30^{\circ} \mathrm{C}$. \\
\hline Treatment 10 & Explant with endophyte $\mathrm{CIM} 1$ incubated at $30^{\circ} \mathrm{C}$. \\
\hline
\end{tabular}


parenchymatous cells in the cortical region arranged in a compact manner without intercellular spaces. The cells maintained their polygonal shape, intact cell wall and homogeneous cytoplasm (Figure 1). In contrast, the damage in explants with $\mathrm{Cr}(\mathrm{VI})$ alone (Treatment 2) might be due to the systemic toxicity caused by high dose of $\mathrm{Cr}$ (VI) $(50 \mu \mathrm{g} / \mathrm{ml})$ (Figure 2). The cells showed intracellular accumulation of $\mathrm{Cr}(\mathrm{VI})$ in the cortical tissues in a particulate fashion within the cortical tissues. Cortical cells became hypertrophied with formation of dark ringed structures while the vascular region was not much affected. In the case of excessive damage, ringed structures were observed at the intercellular locations. The histological changes can be concluded as strong reduction in meristematic activity and hypertrophy of cortical parenchyma. Explants having $\mathrm{Cr}(\mathrm{VI})$ and B. megaterium (Treatments 3) and explants having Cr (VI) and endophyte CIM 1 (Treatment 4) showed less cellular degradation as compared to explants with 50 $\mu \mathrm{g} / \mathrm{ml} \mathrm{Cr}(\mathrm{VI})$ alone (Treatment 2) as is depicted in Figure 3 and 4 respectively. The cortical cells were less enlarged and ringed structures were not observed in the transverse sections of explants having $\mathrm{Cr}(\mathrm{VI})$ and B. megaterium in the growth media. Figure 4 depicts the transverse sections of explants having $\mathrm{Cr}(\mathrm{VI})$ and $\mathrm{CIM} 1$ treatment where microbial inhabitation as hazy growth was observed in the hypodermal regions.

\section{Minimum inhibitory concentration and $\mathrm{Cr}$ (VI) reducing capability}

During the initial screening process, 81 bacterial strains were isolated, out of which two isolates were specifically chosen based on
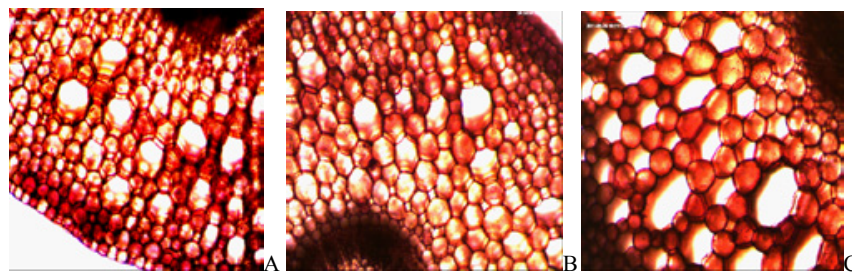

Figure 1: Transverse section of control explants (without $\mathrm{Cr}$ ) showing normal cells with intact cytoplasm.

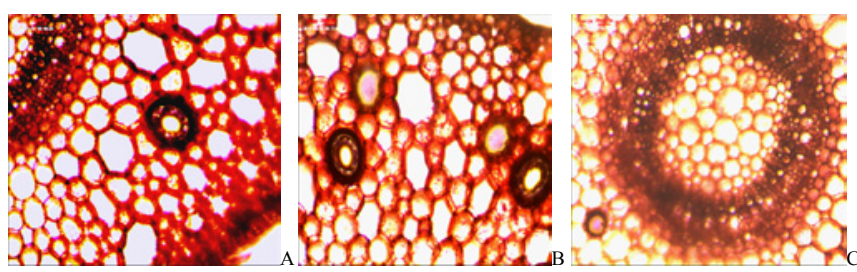

Figure 2: Light micrographs of $\mathrm{Cr}(\mathrm{VI})(50 \mu \mathrm{g} / \mathrm{ml})$ exposed explants (incubation time 21 days)

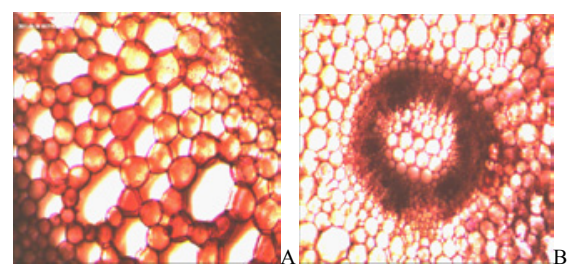

Figure 3: $\mathrm{T}$. S. of explants having $\mathrm{Cr}(\mathrm{VI})$ and $B$. megaterium in the growth media.
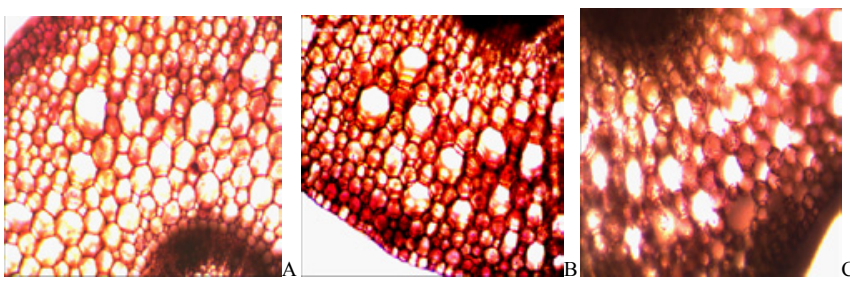

Figure 4: Transverse sections of explants with $\mathrm{Cr}(\mathrm{VI})$ and $\mathrm{CIM} 1$.

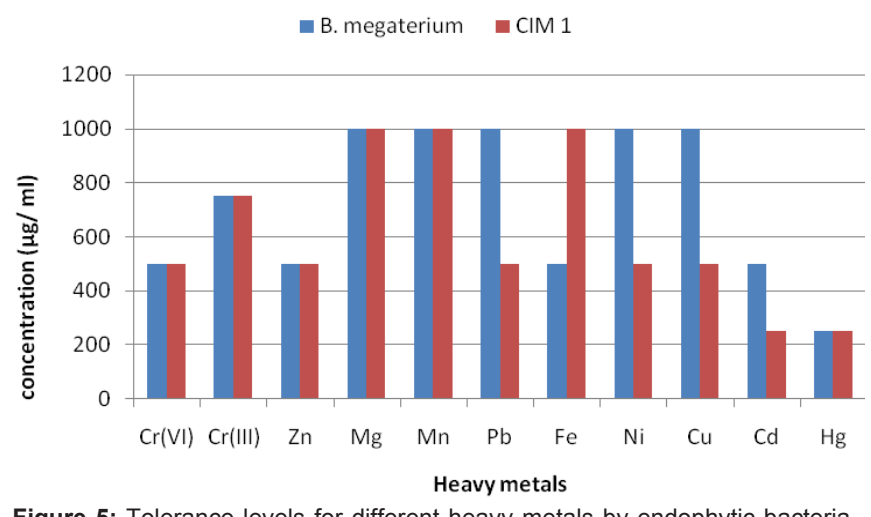

Figure 5: Tolerance levels for different heavy metals by endophytic bacteria (B. megaterium \& CIM 1)

their relatively higher growth efficiency and enhanced tolerance, up to the concentration $50 \mu \mathrm{g} / \mathrm{ml}$ of $\mathrm{Cr}$ (VI). Figure 5 depicts the ability of endophytes to tolerate different concentrations of various heavy metals. The results depicted enhanced tolerance capability for the trivalent form of chromium in the microbes as compared to $\mathrm{Cr}$ (VI). Both the endophytes (B. megaterium \& CIM 1 ) were able to tolerate cent percent concentrations of $\mathrm{Mg}$ and $\mathrm{Mn}$. B. megaterium was more tolerant to metals like $\mathrm{Pb}, \mathrm{Ni}$ and $\mathrm{Cu}$ as compared to endophyte CIM 1. These isolates were able to reduce $\mathrm{Cr}$ (VI), up to $34 \%$ (B. megaterium) and $20.5 \%$ (CIM 1) after 24 hours incubation while more than $50 \% \mathrm{Cr}$ (VI) reduction was observed after 72 hours incubation (Figure 6).

\section{Statistical analysis}

The Duncan test at a level of $5 \%$ of probability was applied. One way analysis of variance ANOVA results for growth promotion revealed significant mean differences against control for plant height, fresh weight and dry weight. Means were compared using the Least Significant Difference (LSD) at probability level (0.05) (Table 2). For plant height, explants incubated at $20^{\circ} \mathrm{C}$ (Treatments $7 \& 8$ ) showed almost same effects while explants exposed to $\mathrm{Cr}$ (VI) were severely affected. Also, temperature variation was not much affecting the plant growth. The explants with different treatments also varied significantly in their fresh and dry weight. CV\% values for plant height provides a quick sight for enhanced plant growth which is not so depicted in the case of fresh and dry weight of the explants. Table 3 depicts a quick analysis for different traits with the F- value showing the significance of the analysis.

\section{RNA isolation and PCR amplification results}

Total RNA when analysed on $1 \%$ agarose gel revealed integrity in the treatments 1, 3 and 4 while damage was detected at RNA level in explants exposed to $\mathrm{Cr}(\mathrm{VI})$ concentrations (Treatment 2) alone which 
was confirmed by cDNA expression with house- keeping actin genes. The cDNA amplification results for SOD and catalase genes (Figure 7) depict amplification in all treatments except for explants exposed to $\mathrm{Cr}$ (VI). The loss of expression in treatment 2 may be attributed to a probable DNA damaging action of $\mathrm{Cr}(\mathrm{VI})$.

\section{Discussion}

Histological methods contribute significantly to our understanding of in vitro culture systems. In vitro selection of plants tolerant to toxic ions contained in the soil may lead to production of plants that are better adapted to environmental pollution and can enable better

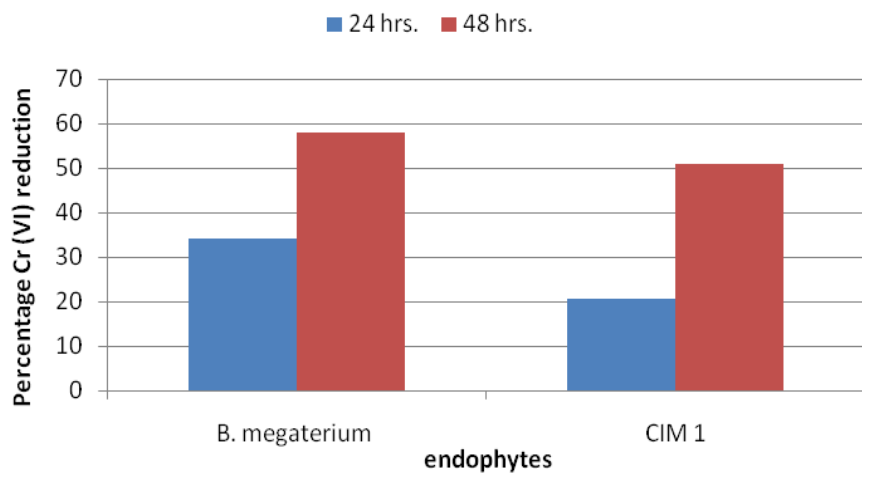

Figure 6: $\mathrm{Cr}(\mathrm{VI})$ Reduction ability of endophytic bacteria (B. megaterium \& CIM 1).

\begin{tabular}{|l|l|l|l|}
\hline Treatment & Plant height $\mathbf{( c m )}$ & $\begin{array}{l}\text { Fresh shoot } \\
\text { weight } \mathbf{( m g )}\end{array}$ & $\begin{array}{l}\text { Dry shoot weight } \\
(\mathbf{m g})\end{array}$ \\
\hline Treatment 1 & $7.37^{\mathrm{c}}$ & $50.67^{\mathrm{a}}$ & $10.27^{\mathrm{a}}$ \\
\hline Treatment 2 & $5.73^{\mathrm{f}}$ & $46.00^{\mathrm{d}}$ & $8.37^{\mathrm{cd}}$ \\
\hline Treatment 3 & $6.67^{\mathrm{de}}$ & $47.13^{\mathrm{cd}}$ & $8.77^{\mathrm{bc}}$ \\
\hline Treatment 4 & $6.47^{\mathrm{e}}$ & $46.73^{\mathrm{d}}$ & $9.03^{\mathrm{b}}$ \\
\hline Treatment 5 & $8.77^{\mathrm{ab}}$ & $42.50^{\mathrm{e}}$ & $7.87^{\mathrm{d}}$ \\
\hline Treatment 6 & $7.07^{\text {cd }}$ & $50.03^{\mathrm{ab}}$ & $10.53^{\mathrm{a}}$ \\
\hline Treatment 7 & $8.23^{\mathrm{b}}$ & $46.47^{\mathrm{d}}$ & $8.83^{\mathrm{bc}}$ \\
\hline Treatment 8 & $8.80^{\mathrm{a}}$ & $48.60^{\mathrm{bc}}$ & $9.07^{\mathrm{b}}$ \\
\hline Treatment 9 & $7.40^{\mathrm{c}}$ & $46.87^{\mathrm{d}}$ & $8.83^{\mathrm{bc}}$ \\
\hline Treatment 10 & $8.73^{\mathrm{ab}}$ & $47.63^{\mathrm{cd}}$ & $9.07^{\mathrm{b}}$ \\
\hline LSD & $\mathbf{0 . 5 2}$ & $\mathbf{1 . 5 3}$ & $\mathbf{0 . 5 3}$ \\
\hline CV\% & $\mathbf{4 . 0 7}$ & $\mathbf{1 . 9 0}$ & 3.43 \\
\hline
\end{tabular}

$\mathrm{CV} \%$ = Variation of coefficient; LSD = least significant difference.

Values in vertical columns followed by different superscripted letters are significantly different at $p<0.05$. Means showing the same letters are not significantly different $(\mathrm{P}=0.05)$ according to Duncan's multiple range test.

Table 2: Growth promotion effect depicted by difference in mean values, their least significant differences (LSD) and coefficient of variation (CV\%).

\begin{tabular}{|l|l|l|l|l|}
\hline $\begin{array}{l}\text { Source of } \\
\text { variation }\end{array}$ & $\begin{array}{l}\text { Degrees of } \\
\text { Freedom }(\mathbf{d f})\end{array}$ & $\begin{array}{l}\text { Plant height } \\
\mathbf{( c m})\end{array}$ & $\begin{array}{l}\text { Fresh } \\
\text { weight }(\mathbf{m g})\end{array}$ & $\begin{array}{l}\text { Dry weight } \\
\mathbf{( m g )}\end{array}$ \\
\hline Treatment & 9 & 31.34 & 139.66 & 17.16 \\
\hline Error & 20 & 1.87 & 16.05 & 1.93 \\
\hline Total & $\mathbf{2 9}$ & 33.21 & $\mathbf{1 5 5 . 7 1}$ & $\mathbf{1 9 . 0 9}$ \\
\hline F- value & & $\mathbf{3 0 . 1 7} * *$ & $\mathbf{1 9 . 3 4} * *$ & $\mathbf{1 9 . 7 9 * *}$ \\
\hline
\end{tabular}

** Significative at a level of $5 \%$ of probability $(p<0.05)$

Table 3: ANOVA table for different growth promoting traits.
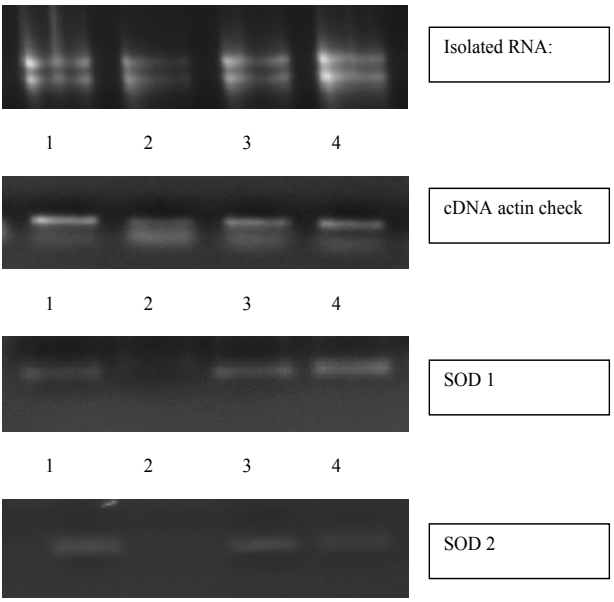

SOD 2

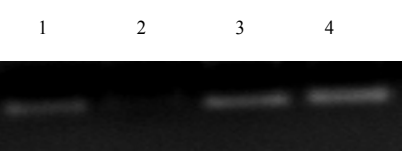

Catalase

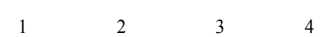

Figure 7: Agarose gel results (Lane1: control explants, Lane 2: with $\mathrm{Cr}(\mathrm{VI})$ (50 $\mu \mathrm{g} / \mathrm{ml})$, Lane 3: $\mathrm{Cr}(\mathrm{VI})$ with B. megaterium and Lane 4: Cr (VI) with CIM 1): depicting expression of RNA and different antioxidant genes.

management of degraded soil for e.g. industrial areas and highways. Plant sensitivity to toxic metal ions depends on the kinds of compounds present in the substrate and on their concentrations. Numerous in vitro experiments have focused on the effects of high concentrations of heavy metals on the regeneration of plants tolerant or sensitive to industrial pollution [16]. Selection of plants under natural conditions of environmental pollution or in vitro may result in the selection of clones tolerant to toxic metal ions. The present study will enable one to select suitable condition and media in vitro. $\mathrm{Cr}$ (VI) induced oxidative stress has been reported as one of the factors resulting in cellular toxicity [17]. $\mathrm{Cr}(\mathrm{VI})$ on reduction generates intermediate species viz. $\mathrm{Cr}(\mathrm{V})$ and $\mathrm{Cr}(\mathrm{IV})$ which further react with $\mathrm{H}_{2} \mathrm{O}_{2}$ to generate more amounts of Reactive Oxygen Species (ROS). It is likely that these ROS may interact with various tissues resulting in their damage. The histological results revealed a significant damage in cortical cells with accumulation of chromium which proves that once inside living tissues; chromium converts its oxidation state and generates ROS [18]. The explants having interface with bacteria were able to withstand $\mathrm{Cr}$ damage indicating that microbial interaction is of assistance to plants. In juxtaposition with many molecular biology methods, histological techniques can provide the necessary information for selection of explants in transformation experiments.

Endophytic bacteria are the bacteria that colonize the internal tissues of the plant showing no external sign of infection or negative effect on their plant host. Bacteria degrading recalcitrant compounds are more abundant among endophytic populations than in the rhizosphere of the plants in contaminated sites, which means that endophytes have a role in metabolizing these substances. The importance of endophytic bacteria in chromium reduction and their ability to promote the plant growth in a metal-contaminated environment has been observed earlier also for bioremediation studies by Rhizobium, Pseudomonas, and Proteous species [19]. The experimentation evaluates the ability of these microbes to show resistance to different heavy metals. The reduced plant growth at chromium concentrations is likely related 
to the alteration of genetic material. These bacteria significantly alter the metabolic and physiological reactions of plant in a precise manner which is revealed through histological, statistical and molecular results. The results are in confirmation with the earlier publications [20]. There are several possible mechanisms by which the bacteria could influence the growth of host plants. The mechanisms include: reduction of $\mathrm{Cr}$ (VI) to Cr (III) by which it reduces the toxic effects of $\mathrm{Cr}$ (VI) to the plants; synthesis of siderophore, which can solubilise and sequester iron from the soil; production of phytohormones, which can enhance the growth of plants and solubilisation of phosphorus. Hence, the plant growth-promoting characteristics by the Cr tolerant $\mathrm{Cr}$ (VI) reducing endophytes should be screened for their multifarious roles in remediation strategies.

Chromium stress can induce three possible types of metabolic modification in plants (i) alteration in the production of pigments which are involved in the life sustenance of plants (e.g., chlorophyll) ; (ii) increased production of metabolites (e.g., glutathione, ascorbic acid) as a direct response to $\mathrm{Cr}$ stress which may cause damage to the plants and (iii) alterations in the metabolic pool to channelize the production of new biochemically related metabolites which may confer resistance or tolerance to $\mathrm{Cr}$ (VI) stress (e.g., phytochelatins, histidine). The effect of $\mathrm{Cr}(\mathrm{VI})$ on the plant processes during early growth and development culminates in reduction of yield and total dry matter as a consequence of poor production, translocation and partitioning of assimilates to the economic parts of the plant. The negative effect on yield and dry matter is essentially an indirect effect of $\mathrm{Cr}$ (VI) on plants. The results for one way analysis of variance are in confirmation with these findings, showing enhanced growth in treatments having microbial support. Adverse effects of $\mathrm{Cr}$ on plant height and shoot growth were detected in our investigation which is in coordination of earlier reports [21]. In a study conducted on Vallisneria spiralis to evaluate the $\mathrm{Cr}(\mathrm{VI})$ accumulation and toxicity in relation to biomass production, it was found that dry matter production was severely affected by $\mathrm{Cr}$ (VI) concentrations [22]. Synergistic effect of microbes on efficient shoot induction has been well documented and proved in the following plant species: Dianthus chinesis; Rhodiola rosea; Salvia nemorosa. [23,24].

Induction and activation of Superoxide dismutase (SOD) and catalase are some of the major metal detoxification mechanisms in plants [25]. Alteration of antioxidant enzymes due to metal inhibition has been reported [26] which are in accordance to the present results. A high concentration of ROS generated due to $\mathrm{Cr}(\mathrm{VI})$ at cellular level is because of oxidative stress which explains most of the visual Cr (VI) toxicity symptoms observed at whole plant level. High ROS production by $\mathrm{Cr}$ (VI) could set in motion a chain of signalling response at gene expression level which in turn could increase active scavenging. Higher energy allocation for active scavenging could deprive the plant of its quota of energy required for normal growth.

\section{Conclusions}

Having revised the overall picture of $\mathrm{Cr}$ (VI) toxicity in plants, it is clear that the species of $\mathrm{Cr}(\mathrm{VI})$ are toxic at different degrees at different stages of plant growth and development and also that the toxicity is concentration and medium dependent. The toxic properties of $\mathrm{Cr}$ (VI) originate from the action of this form itself as an oxidizing agent, as well as from the formation of free radicals during the reduction of $\mathrm{Cr}$ (VI) to $\mathrm{Cr}$ (III) occurring inside the cell. Thus, one of the future challenges to understand $\mathrm{Cr}(\mathrm{VI})$ toxicity would be to unravel the complete picture of interconversion of the $\mathrm{Cr}$ (VI) species within the plant system, after its uptake, on a time course at environmentally relevant concentrations with emphasis at different stages of plant development. In conclusion, the present study elucidates the adverse effects of $\mathrm{Cr}$ (VI) on the cellular integrity in B. monneirri; results also suggest that the overall toxic impacts occur at multiple sites and the long-term exposures to this heavy metal might pose a potential risk to native flora in the vicinity of contaminated sites.

\section{Significance of the Work}

Chromium is an extensively used anthropogenic pollutant causing severe damage to living cells. In aqueous systems, $\mathrm{Cr}(\mathrm{VI})$ exists as oxyanions $\left(\mathrm{CrO}_{4}{ }^{2}\right)$ which are structurally analogous to sulphate and phosphate ions thus can be easily incorporated with the anionic transport system. The entry of $\mathrm{Cr}(\mathrm{VI})$ in living cells results in ROS (reactive oxygen species generation) causing damage to DNA and exerting mutagenic and teratogenic effects. The present study accounts for investigating the cellular level changes in Bacopa monneiri after short-term exposure to $\mathrm{Cr}(\mathrm{VI})$ so as to assess the toxicity induced due to chromate. Bacopa monneiri is a medicinally important plant inhabiting the moist places nearby rivers and lakes. If such plants are either naturally grown or cultivated in meta contaminated regions, there is a danger that the heavy metal accumulation by plants of medicinal value may cause serious health hazards to patients using meta adulterated herbal drugs. The histological studies are noteworthy to understand the changes in structural organization that occur due to pollutants in the environment The damage due to $\mathrm{Cr}(\mathrm{VI})$ was assessed on DNA so that the molecular relationship could be established.

\section{Acknowledgements}

The authors thank Council of Scientific and Industrial Research, New Delhi, India for providing financial support and Director, CSIR-Central Institute of Medicinal and Aromatic Plants, Lucknow (India), for encouragement and facilities.

\section{References}

1. Cervantes C, Campos-García J, Devars S, Gutiérrez-Corona F, Loza-Tavera $\mathrm{H}$, et al. (2001) Interactions of chromium with microorganisms and plants. FEMS Microbiol Rev 25: 335-347

2. Klaassen CD, Watkins JB (1991) Toxic effects of metals In: Amer MO, Doull J, Klaassen CD (ed.) Casarett and Doull's Toxicology: Basic science of poisons. Pergmon Press, Oxford.

3. Dixit V, Pandey V, Shyam R (2002) Chromium ions inactivate electron transport and enhance superoxide generation in vivo in pea (Pisum sativum L.cv. Azad) root mitochondria. Plant Cell \& Environ 25: 687- 693.

4. Panda SK, Patra HK (2000) Nitrate and ammonium ions effect on the chromium toxicity in developing wheat seedlings. Proceedings of the National Academy of Sciences, India Section B: Biological Sciences.70: 75-80.

5. Jain R, Srivastava S, Madan VK (2000) Influence of chromium on growth and cell division of sugarcane. Indian Journal of Plant Physiology 5: 228-231.

6. Singh AK (2001) Effect of trivalent and hexavalent chromium on spinach (Spinacea oleracea L). Environment and Ecology 19: 807-810.

7. Kotas J, Stasicka Z (2000) Chromium occurrence in the environment and methods of its speciation. Environ Pollut 107: 263-283.

8. Shukla OP, Dubey S, Rai UN (2007) Preferential accumulation of cadmium and chromium: toxicity in Bacopa monnieri. L. under mixed metal treatments. Bull Environ Contam Toxicol 78: 252-257.

9. Kirmani MZ, Sheikh M, Naz F, Naqvi II, Zahir E (2011) Determination of some toxic and essential trace metals in some medicinal and edible plants of karachi city. Journal of Basic and Applied Sciences 7: 89-95.

10. Stough C, Lloyd J, Clarke J, Downey LA, Hutchison CW, et al. (2001) The chronic effects of an extract of Bacopa monniera (Brahimi) on cognitive function in healthy human subjects. Psychopharmacology (Berl) 156: 481-484.

11. Ali G, Srivastava PS, Iqbal M (2001) Responses of Bacopa monnieri cultures to cadmium toxicity. Bull Environ Contam Toxicol 66: 342-349.

12. Vijaymadhavan KT, Iwai $T$ (1975) Histochemical observations on the permeation of heavy metals into taste buds of goldfish. Bull Jap Soc Sci Fish 41: 631-639.

13. Murashige T, Skoog F (1962) A Revised Medium for Rapid Growth and Bioassays with Tobacco Tissue Cultures. Physiol Plant 15: 473-497. 
Citation: Shilpi Khare S, Arun Kumar M, Sudeep T, Rakesh P (2012) Hexavalent Chromium Induced Histological Alterations in Bacopa monnieri (L.) and Assessment of Genetic Variance. J Cytol Histol 3:141. doi:10.4172/2157-7099.1000141

14. Tiwari V, Singh BD, Tiwari KN (1998) Shoot regeneration and somatic embryogenesis from different explants of Brahmi (Bacopa monniera (L.) Wettst). Plant Cell Rep 17: 538-543.

15. Lenore SC, Franson MAH(1998) Standard methods for the examination of water and wastewater, 20th ed. Washington, DC: American Public Health Association, APHA.

16. Aruldhas MM, Subramanian S, Sekar P, Vengatesh G, Chandrahasan G, et al. (2005) Chronic chromium exposure-induced changes in testicular histoarchitecture are associated with oxidative stress: study in a non-human primate (Macaca radiata Geoffroy). Hum Reprod 20: 2801-2813.

17. Begum G, Venkateswara RJ, Srikanth K (2006) Oxidative stress and changes in locomotor behavior and gill morphology of Gambusia affinis exposed to chromium. Toxicol Environ Chem 88: 355-365.

18. Zayed AM, Terry N (2003) Chromium in the environment: factors affecting biological remediation. Plant Soil 249: 139-156.

19. Bano N, Musarrat J (2003) Characterization of a new Pseudomonas aeruginosa strain NJ-15 as a potential biocontrol agent. Curr Microbiol 46: 324-328.

20. Losi ME, Amrhein C, Frankenberger WT Jr (1994) Environmental biochemistry of chromium. Rev Environ Contam Toxicol 136: 91-121.
21. Nichols PB, Couch JD, Al-Hamdani SH (2000) Selected physiologica responses of Salvinia minima to different chromium concentrations. Aquat Bot 68: 313-319.

22. Vajpayee $P$, Rai UN, Ali MB, Tripathi RD, Yadav V, et al. (2001) Chromium induced physiologic changes in Vallisneria spiralis $\mathrm{L}$. and its role in phytoremediation of tannery effluent. Bull Environ Contam Toxicol 67: 246-256.

23. Kanita A, Kothari SL (2002) High efficiency adventitious shoot bud formation and plant regeneration from leaf explants of Dianthus chinensis L. Scientia Horticulturae 96: 205-212.

24. Skala E, Wysokinska $H$ (2004) In vitro regeneration of Salvia nemorosa L. from shoot tips and leaf explants. In Vitro Cell Dev Biol Plant 40: 596-602.

25. Shanker AK, Djanaguiraman M, Sudhagar R, Chandrashekar CN Pathmanabhan G (2004) Differential antioxidative response of ascorbate glutathione pathway enzymes and metabolites to chromium speciation stress in green gram (Vigna radiata (L) R Wilczek, cv CO 4) roots. Plant Sci 166 1035-1043.

26. Gwozdz EA, Przymusinski R, Rucinska R, Deckert J (1997) Plant cell responses to heavy metals: molecular and physiological aspects. Acta Physiol Plant 19: 459-465. 